\title{
MACEDÓNSKA DRÁMA NA SLOVENSKU PO ROKU 1989
}

\author{
ZVONKO TANESKI
}

Filozofická fakulta Univerzity Komenského, Bratislava

\begin{abstract}
Abstrakt: Ciel'om príspevku je preskúmat recepciu macedónskej drámy na Slovensku po roku 1989 a poskytnút obraz o vydaných knižných prekladoch týchto drám v sledovanom období. Autor sa v rámci vymedzenej témy zameriava predovšetkým na poetiku dislokácie a problematiku literárnej migrácie a jej modifikácie. Jeho ambíciou je predložit dokument, ktorý bude referovat’ o charaktere, osobitostiach a špecificky určenej forme prítomnosti macedónskej drámy v slovenskom kultúrnom prostredí, pričom na skúmaný fenomén nahliada z interdisciplinárneho hl'adiska a paralelne z viacerých uhlov pohladu.
\end{abstract}

Klúčové slová: macedónska dráma, dislokácia, recepcia, slovenský kultúrny kontext

Prezentácia a interpretácia preložených drám by mala byt’ z aspektu prekladatel'skej a pôvodnej produkcie reprezentatívna a ojedinelá pre vednú oblast', v ktorej sa výskum realizoval. Autor predkladanej štúdie sa zaoberá výskumom južnoslovanských literatúr a ich recepcie na Slovensku po roku 1989 až do súčasnosti, a to v širšom spoločensko-politickom kontexte. Je si vedomý toho, že takto postavený projekt má nielen enormné rozmery, ale aj polemický charakter koncepcie, ktorá odporuje tradičným dejinám literatúr založeným na nacionalistických predpokladoch a orientovaným výlučne na literárne texty. V tejto štúdii sa sústred’uje len na jeden zo segmentov svojho bádania - na dramatickú tvorbu Macedóncov a jej prekladatel'skú reflexiu na Slovensku v uvedenom období. Ciel’om výskumu je priniest’ aktuálne, exaktné poznatky o novšej dramatickej tvorbe Macedóncov a jej súčasných trendoch, o literárnom a kultúrnom odkaze macedónskych dramatických diel, aj o význame jednotlivých umeleckých knižných prekladov z macedónskej drámy na Slovensku. V tejto fáze výskumu si nenárokuje na úplnost’ a definitívnost̉ predložených tvrdení a záverov. Ide skôr o priebežný popis stavu, o obraz toho, v akých referenčných, tematických, obrazných a výrazových intenciách a podobách sa javia skúmané procesy migrácie či dislokácie, resp. ktoré paradigmaticko-štrukturálne zmeny a posuny v samotných dramatických dielach sú prejavom či dôsledkom širších, všeobecnejších kultúrnych pohybov. ${ }^{1}$

Úvodným krokom pri každej vstupnej „diagnostike“ je pomenovanie problému, ked’že práve ono predstavuje prvú fázu jeho prekonávania. Preto považujeme za primárnu úlohu vypovedat’ o celku a až neskôr spomínaný problém podrobnejšie preskúmat’ a dopracovat' sa k potrebným výsledkom. Tu je dôležité poznamenat', že hoci ide o pomerne dlhé časové obdobie (1989 - 2019), mapovaný priestor nie je vel'mi

\footnotetext{
${ }^{1} \mathrm{~V}$ tomto zmysle môžeme hovorit’ o dramatikoch, ktorí určité obdobie života prežili a tvorili v zahraničí a práve táto dislokácia zanechala výraznú pečat’ v ich tvorbe. Týka sa to aj macedónskych dramatikov - Gorana Stefanovského žijúceho vo Vel’kej Británii a Jordana Plevneša žijúceho vo Francúzsku.
} 
rozsiahly, ked’že tradícia prekladania i uvádzania macedónskej drámy na Slovensku je minimálna, rovnako tak aj tradícia jej recepcie. ${ }^{2} \mathrm{~V}$ súčasnosti výskum macedónskej drámy na Slovensku absentuje z niekol'kých klúčových dôvodov. V prvom rade preto, že tu, na rozdiel od napr. Vel'kej Británie, Francúzska či USA, nie sú macedónske drámy publikované vo vel'kých vydavatel'stvách, ktoré majú aktívnu distribučnú a predajnú siet', ale v malom vydavatel’stve „,jedného človeka“ a v nízkom náklade. ${ }^{3}$ Zároveň sa na Slovensku doposial’ nevyprofiloval žiadny filológ so špecializáciou na macedónčinu, preklady teda vznikajú z osobnej zaangažovanosti či zanietenia niektorých slovenských prekladatel'ov, pričom ide zväčša o nekomerčné, nezištné, ba doslova „fanúšikovské“ pracovné projekty. Sú motivované individuálnym vkusom a znalostou macedónskeho kultúrneho kontextu, ktorý, napriek geografickej blízkosti, je slovenskému príjemcovi stále relatívne neznámy, najmä ak ide o aktuálnu situáciu na južnoslovanskej literárnej scéne. Dokonca aj teoretická príručka k písaniu hier s názvom Malá kniha nástrah (2010) od macedónskeho dramatika Gorana Stefanovského bola preložená do slovenčiny z anglického jazyka. ${ }^{4}$ Väčšina z preložených drám macedónskych autorov mala na Slovensku minimálne recenzné ohlasy a ich charakter bol, vzhl'adom na už spomenutú neprítomnost' odborníkov špecializujúcich sa na macedónsku drámu, o čosi menej „zasvätený“ než pri analýzach diel z viac známych literatúr. Z vyššie uvedeného vyplýva, že frekvencia vydávania prekladov z macedónskej drámy je nepredvídatelná, determinovaná hlavne mierou osobného nadšenia prekladatel'ov a taktiež mierou ochoty konkrétnej grantovej agentúry podporit knižný preklad z macedónčiny.

V predkladanom príspevku sa zameriavame na tých macedónskych dramatikov, ktorých diela boli po roku 1989 preložené do slovenčiny a vyšli knižne. Vymedzenie rokmi 1989 až po užšie chápanú súčasnost', teda po rok 2019, sme si stanovili s prihliadnutím na kultúrne procesy v transformujúcej sa slovenskej i macedónskej spoločnosti. Napokon, rok 1989 je politicko-historickým medzníkom práve z hladiska zmeny režimu, ktorá je predpokladom a začiatkom následných celospoločenských kultúrnych premien. Následne sa na vzorke vybraných textov pokúšame načrtnút problém slovenskej prekladovej reflexie macedónskej drámy, zohl'adňujúc rôzne úrovne celospoločenskej transformácie i najnápadnejších, vo všeobecnosti najpríznačnejších civilizačných trendov dneška. Takýto synekdochický výber sa pritom ukázal byt’ podstatne

\footnotetext{
${ }^{2}$ Velmi slabú prítomnost’ macedónskej drámy na Slovensku v porovnaní s prítomnostou dramatickej tvorby iných národov bývalej Juhoslávie či Bulharska zaznamenávame aj pred rokom 1989. Viac pozri TANESKI, Z. Dramatická tvorba v slovensko-macedónskych kultúrnych vztahoch od druhej polovice 20. storočia po súčasnost'. In Slovenské divadlo, 2009, roč. 57, č. 2-3, s. 176 - 185; tiež TANESKI, Z. Slovensko-macedónske literárne a kultúrne vzt’ahy. Bratislava : Juga / Ústav svetovej literatúry SAV, 2009, s. 131 - 142.

${ }^{3}$ Navyše, aj dve drámy macedónskeho spisovatel’a Gorana Stefanovského boli predtým, než vyšli knižne, publikované v slovenčine v periodickom časopise Javisko. (STEFANOVSKI, G. Divé mäso (Диво месо). Prel. J. Jankovič. In Javisko, 1989, roč. 21, č. 1, s. 17 - 33; STEFANOVSKI, G. Tetované duše (Тетовирани души). Prel. J. Jankovič. In Javisko, 1994, roč. 26, č. 6, s. $19-29$.

${ }^{4}$ Pozri STEFANOVSKI, G. Malá kniha nástrah (príručka na písanie hier). Z angličtiny prel. K. Slugeňová-Cockrell, P. Kerlik. Bratislava : Divadelný ústav, 2010. Publikácia je určená v prvom rade pre študentov, ako metóda priameho vyučovania písania hier. Autor čitatel’om ponúka množstvo praktických cvičení, v ktorých si osvojené vedomosti preskúšajú a overia v praxi. V skúmaných súvislostiach však bolo dôležité spomenút’ aj tento knižný titul, ked’že pri ňom by sa pod dislokáciou mohlo rozumiet pôsobenie autora vo Vel'kej Británii (žil a tvoril v anglickom meste Canterbury, kde pôsobil ako univerzitný profesor teatrológie). Dôsledkom jeho emigrácie bolo i to, že kniha je do slovenčiny preložená z anglickej a nie z originálnej macedónskej predlohy.
} 
problematickejší než časové vymedzenie pojmu „súčasná macedónska dráma“. Problém nepredstavovala otázka, čo možno pod týmto pojmom chápał’ z periodizačného hl'adiska, ale najmä, čo do macedónskej drámy a do slovenskej prekladovej produkcie z vybraných rokov patrí, ktorí autori a diela by v informatívnom prehlade literatúry tohto obdobia nemali chýbat. Uvedené sa pritom stáva ešte problematickejším, ak si položíme d’alšie otázky: Ktorí z autorov staršej či najstaršej generácie - žijúcich, ale tiež už nežijúcich ${ }^{5}$ klasikov, ktorých vrchol tvorby spadá prevažne do osemdesiatych alebo devät’desiatych rokov - si v nej udržiavajú určujúcu pozíciu aj v rámci dnešnej literárnej scény? ${ }^{6}$ Kto utvára profil literárnej, resp. dramatickej súčasnosti u Macedóncov a kto následne na Slovensku? Možno vôbec hovorit’ v tomto zmysle o nejakom zretel'nom či ustálenom profile, či nebodaj o kánone širšie ponímanej súčasnej macedónskej drámy? Rad d’alších otáznikov následne vyplynie pri zohladnení axiologických, vydavatel'sko-distribučných, komerčných, mediálno-komunikačných, ale aj literárno-sociologických, generačno-skupinových a iných aspektov.

Ked’že hlavnou snahou výskumu bolo čo najplastickejšie postihnút dramatickú reflexiu najzjavnejších, najpríznačnejších trendov dneška, pri prezentácií diel sme prednostne prihliadali na tematický či námetovo-koncepčný aspekt. Uprednostnili sme také zložky textov, v ktorých sa ako relevantné, explicitne výpovedné dominanty objavujú problematika migrácie a poetika dislokácie. Otázky vlastnej literárno-umeleckej hodnoty a kvality prekladu - teda axiologický zretel' - neboli pre nás vždy nevyhnutne smerodajné, preto sme ich predbežne ponechali bokom. Ovel'a relevantnejšie bolo stanovit’ si na základe načrtnutých zásad a východísk presné problémové okruhy bádania. Táto skutočnost’ viedla k vymedzeniu vlastnej metodologickej osnovy práce v nasledovných základných pracovných bodoch, ktoré boli rozhodujúcimi pri spracovávaní ponúknutých sond do migrácií v macedónskej dráme po roku 1989:

- východiskové zmapovanie aktuálneho stavu výskumnej problematiky od roku 1989 po súčasnost' (2019),

- identifikácia a charakteristika klúčových motívov spojených s tematikou migrácie alebo s poetikou dislokácie,

- identifikácia osudov autorov a charakteristika ich hodnotových postojov k aktuálnym procesom migrácie a dislokácie,

- porovnanie postojov k migračno-dislokačnej realite - pokus o predbežné zhodnotenie,

- rozličné autorské a generačné platformy a koncepcie reflektovania problematiky,

- referenčné rámce, modality, resp. intencie pri sledovaní fenoménu dislokácie a migrácie,

- otázka migračno-dislokačnej identity výpovedného, resp. autorského subjektu (kategória hlavného alebo niektorého vedliajšieho protagonistu v dráme),

\footnotetext{
${ }^{5} \mathrm{~V}$ tomto prípade je otázne, či status „nežijúci“ nekoliduje s vyššie postulovaným pojmom „súčasní“, ak pravdaže nepokladáme za súčasnost’ všetko po roku 1945, ako sa s tým ešte aj dnes stretávame v niektorých učebniciach literatúry, resp. literárnohistorických príručkách. V našom prípade treba podotknút, že práve jeden z dvoch tu predstavovaných macedónskych dramatikov, G. Stefanovski, je už nežijúci a jeho tvorivý opus je ukončený.

${ }^{6}$ Popri preložených dramatikoch G. Stefanovskom a J. Plevnešovi treba spomenút aj d’alších autorov z tohto korpusu, napr. Rusomira Bogdanovského (1948), Dejana Dukovského (1969), Venka Andonovského (1964), Saška Naseva (1966), Jugoslava Petrovského (1969) a Žaninu Mirčevskú (1967), ktorých dielo v uplynulých rokoch rezonovalo $\mathrm{v}$ pre nás blízkom českom prostredí.
} 
- otázka vzt’ahu dramatikov k domácej národnokultúrnej tradícii a ich cesta $\mathrm{k}$ jej hodnotám,

- široký priemer migračno-dislokačných trendov v rovine výrazových prostriedkov (jazyk diela a hlavné tematické jadrá v texte).

Pri pohl'ade na bibliografický súpis publikovaných prekladov z macedónskej drámy v skúmanom období je zrejmé, že ide o nízky počet titulov, a to iba od dvoch autorov, Gorana Stefanovského (1952 - 2018) a Jordana Plevneša (1953). I takáto skromná prekladová tvorba však otvorila inšpiratívny priestor pre d’alší výskum vzt’ahov, ktoré môžu v súčasnom procese globalizácie a podmienkach multikultúrnej spoločnosti nadobudnút nové rozmery. Preto sme sa sústredili práve na poetiku dislokácie a problematiku migrácie, čiže na témy otvárajúce otázky existencie v cudzine, v emigrácii alebo v exile. Menovaní dramatici aj protagonisti ich literárnych diel si presne uvedomujú, odkial' pochádzajú, a vnímajú inakost’ nového priestoru. Často reagujú na traumu vykorenenia (znovu)vytvorením koreňov a idealizovaním domova, ktorý možno nikdy nemali.

Goran Stefanovski, jeden z medzinárodne najrešpektovanejších intelektuálov pochádzajúcich $\mathrm{z}$ bývalej Juhoslávie, predstavoval osobitý zjav nielen $\mathrm{v}$ macedónskej dramatickej literatúre, ale i v širšom balkánskom priestore. Bol umelcom svetobežníkom, pokúšajúcim sa byt’ autorom medzi dvoma jazykmi a dvoma kultúrami. Striedavo žil a tvoril vo svojej vlasti i v cudzine, jeho hry sa hrali a publikovali v celej Európe i v zámorí. Svetové premiéry niektorých jeho hier sa konali v západoeurópskych metropolách, bol nositel'om mnohých domácich i zahraničných ocenení.

Slovenské súborné vydanie jeho diel s názvom Tetované duše (Vybrané dramatické práce) vyšlo v roku 2009 vo Vydavatel’stve Jána Jankoviča - Juga a obsahuje drámy Let na mieste (1981), Tetované duše (1985), Živé mäso (1979), Hocikto (2002), Čierna diera (1987) a Hi-Fi (1982). ${ }^{7}$ Ide o výnimočný edičný čin, a to aj vd’aka rozsiahlemu, erudovanému predhovoru Jána Jankoviča. Tento prekladatel' a neskôr i vydavatel' diel macedónskych dramatikov na Slovensku napísal viacero rozsiahlych analytických štúdií, ktoré boli uverejnené ako predhovory knižných vydaní, prípadne ako samostatné štúdie $\mathrm{v}$ domácich vedeckých reprezentatívnych zborníkoch. ${ }^{8} \mathrm{~V}$ nich sa dotýkal aj recepcie d’alších významných autorov z priestoru bývalej Juhoslávie, ktorých prekladal do slovenčiny a prezentoval v slovenskom kultúrnom prostredí. ${ }^{9} \mathrm{~V}$ predhovore k Tetovaným dušiam popisuje a vysvetl'uje nielen špecifiká Stefanovského života a tvorby, ale aj jeho význam a prínos pre slovenské kultúrne vedomie. Súborné vydanie obohacujú dva komplexné rozhovory, ktoré Stefanovski poskytol macedónskym médiám $v$ devätdesiatych rokoch minulého storočia. Jeho pohl'ad na svet ponúka mnoho podnetov aj pre slovenských čitatel’ov a najmä divadelníkov, ktorí majú zá-

\footnotetext{
${ }^{7}$ Drámy sú v súbornom vydaní publikované v tomto poradí.

${ }^{8}$ JANKOVIČ, J. Goran Stefanovski a macedónska dráma. Predhovor. In STEFANOVSKI, G. Tetované duše (Vybrané dramatické práce). Bratislava : Juga, 2009, s. 7 - 23; JANKOVIČ, J. Súvislosti alebo konspekt dejín macedónskej drámy. In Tamže, s. 39 - 59; JANKOVIČ, J. Jordan Plevneš - vzácny hosṫ z Macedónska. Predhovor. In PLEVNEŠ, J. „R“ - Dramatický sen so striel'aním do abecedy v 15 obrazoch. Bratislava : Juga, 2010, s. 5 - 15; JANKOVIČ, J. Konspekt macedónskej drámy (po nástup Gorana Stefanovského). In Philologica LXVII - Universitas Comeniana (Zborník Filozofickej fakulty Univerzity Komenského). Bratislava : Univerzita Komenského, 2011, s. 169 - 183.

${ }^{9}$ Pozri napr. JANKOVIČ, J. Chorvátske, macedónske, slovinské a srbské dramatické texty na Slovensku (Niektoré problémy a ich riešenia). In P. Winczer a kol. K otázkam teórie a dejín prekladu na Slovensku I., Bratislava : Ústav svetovej literatúry SAV, 1993.
} 
ujem dôkladnejšie spoznat’ tohto medzinárodne známeho dramatika. Napokon, sám Stefanovski neraz zdôraznil, že sa usiluje písat’ texty, ktoré budú rôzni režiséri čítat' v ideálnom prípade ako „predtexty“, ktoré sa dajú aplikovat’ v každom čase, v podmienkach nových a odlišných kontextov.

Drámu Let na mieste označil Stefanovski ako divadelnú fresku. Dej zasadil do historicky významného roku 1878, ked’ boli na dennom poriadku krvavé revolty za národné a sociálne oslobodenie. Relatívne široký register postáv reprezentuje všetky rozhodujúce ludské faktory súdobej politickej situácie v tomto kúte Balkánu: popri Macedóncoch sú tu Turci, Gréci, Srbi, Bulhari. Štruktúra postáv odráža skutkový stav na mieste konania drámy. Macedónci sú najpočetnejší (žijú na vlastnom území) - tento fakt súčasne umožňuje postihnút plnost’ i tragiku národného vývinu, t. j. vidiet život v jeho zložitosti a rozpornosti. Sila Stefanovského metafory sa prejavuje aj v tom, že napriek dobovým kostýmom možno jeho postavy vnímat’ ako l'udí dneška, ktorí sú rovnako zat’ažení predsudkami, vzájomnými konfliktami, vlastnými tragédiami, neschopnostou nájst’ seba samých i východisko zo svojej situácie. Migrácia obyvatel'stva bola aj v tomto období bežne rozšíreným javom. História zaznamenala rad prípadov, ked' Macedóncov neohrozovalo len vonkajšie nebezpečenstvo. V hre ide o vztahah jednotlivca $\mathrm{k}$ akcii, o individuálny čin v rámci všeobecných túžob, o presvedčenie, že človek je povinný konat', hoci výsledok je neistý a vzdialený a ciele sú takmer neuskutočnitel'né. Lebo pokus letiet', ked' sa lietat' nedá, je činom pre národ i pre jednotlivca. A netreba zabúdat ani na to, že ak naozaj "miesto poletí" s tebou, bude to dôkaz opodstatnenosti viery, že aj nemožné sa raz môže stat možným.

Dianie v dráme Hi-fi nie je viazané na slobodu národa, ale na slobodu jednotlivca. Fabula hry je priamočiara. Hlavný protagonista Boris sa po rokoch vracia domov (prichádza z väzenia a len z náznakov je jasné, že bol politickým väzňom) a vo svojom byte nájde vnuka Mateja, ktorý obrátil celý príbytok hore nohami. Stala sa z neho ubytovňa, v ktorej môže pobudnút každý, komu sa zachce - náhodný americký turista i ruský lektor. Matejova matka žije s Arabom. Dedo, odchovanec starej politiky, sa pokúša priviest' slobodomysel'ného, l'ahtikárskeho vnuka k rozumu. Ked' nepomôže ani ostrihanie jeho dlhých vlasov, tak ho „zatkne“, poviaže, začne s výsluchmi a prevýchovou. No po krátkom pocite vítazstva zistí, že on sám bol porazený. V hre, ktorej nechýba satirický akcent, nejde o konflikt generácií, ako by sa mohlo na prvý pohlad zdat', ale o konflikt dvoch princípov, pričom sú oba mylné.

Hru Tetované duše napísal autor po kratšom pobyte v USA. Opätovne siahol po národnej téme, ktorú tentoraz spracoval cez prizmu vystahovalectva. Stefanovski o hre hovorí: „Pozornost’ som venoval vyst’ahovalectvu, trvalej téme nášho priestoru, aby som sa na tému pozrel z inej strany. My nelutujeme vystahovalcov, ale ani oni nelutujú nás. Najstrašnejšou emigráciou je tá, ktorá sa nekoná fyzicky. Ked’ sa stratí vôla, ked’ sa odíde do duševného exilu, do vnútorného sebavyhnanstva. Tetované duše sú hrou o úbohých lud’och, ktorí sa na svojom bezhlavom úteku pred slobodou tetujú hocičím: nacionalizmom, vulgárne pochopeným marxizmom, sexom, drogou alebo rokenrolom. " ${ }^{10}$

Hra Živé mäso, ktorú Stefanovski písal paralelne so svojou magisterskou prácou o majstrovi absurdného divadla Samuelovi Beckettovi, sa odohráva v predvečer 2. svetovej vojny v Skopje, vo štvrti Debar maalo. V pôdoryse drámy je badatelný

${ }^{10}$ Cit. podl’a JANKOVIČ, J. Goran Stefanovski a macedónska dráma. Predhovor, s. 16 - 17. 
princíp rozprávkovosti. Ústrednými postavami sú traja bratia rozličných charakterov, synovia matky s črtami vedmy a bylinkárky, ktorá niekedy nemá d’aleko od extázy. Ďalšími protagonistami hry sú postavy z „iných královstiev“, pravdaže, adekvátne dobe a miestu konania drámy: intelektuál a predstavitel' nemeckej firmy, Žid a jeho dcéra, srbský poradca. Ústredným motívom hry je strach z toho, že cudzí element zničí macedónsky národ. Symbolika l’udovej rozprávky sa prejavuje nielen $\mathrm{v}$ počte bratov, ale aj $\mathrm{v}$ tom, že sa príbeh odvíja na pozadí výstavby nového domu. Symbolický, ale z reality vychádzajúci je i záver hry, v ktorom z domu ostanú len ruiny, lebo sa stal prvou obetou fašistickej expanzie.

Aj dráma Čierna diera má univerzálnu dimenziu. Hlavný hrdina sa volá Siljan, pričom jeho meno je klúčom k pochopeniu hry - existuje totiž macedónska l’udová rozprávka Siljan štrkot (Bocian Siljan). Hra je v rozprávke zakotvená len jednou (bociaňou) nohou. Druhou sa opiera o dobovú realitu, rozprávajúc o traume jednotlivca a spoločnosti krátko pred dramatickým rozpadom Juhoslávie, ktorého príčiny viseli vo vzduchu už dávnejšie. Dej sa koncentruje okolo lásky, smrti a občianskej vojny.

Podobné témy, úzko spojené s poetikou dislokácie, spracúva i Stefanovského novšia dráma Hocikto (2002). Hlavná postava, Anastázia, je tu predstavená iba ako „cudzinka“. Sama sa však prezentuje ako smrt’, resp. „čierny anjel osudu“"11. Dej sa odohráva prevažne v jednom španielskom hoteli. Dalšími protagonistami sú šiesti turisti - sebeckí a posadnutí samými sebou. Anastázia „(...) prišla, aby ukázala týmto nafúkaným smrtel'níkom, kto vládne. Kto má posledné slovo. "12 Podobne ako ostatné autorove tituly, aj hra Hocikto zaznamenala medzinárodný úspech (dlho sa uvádzala najmä v Skopje, Belehrade a Londýne).

Podobne ako Goran Stefanovski, aj Jordan Plevneš je súčasne macedónskym i svetovým autorom, ktorému sú rovnako blízke národné témy, ako aj témy so širšími spoločensko-politickými súvislostami, vytvárajúce univerzálnu pôdu pre jeho hry. Plevnešova medzinárodná kariéra je bohatá - bol napr. vel’vyslancom Macedónska vo Francúzsku, Španielsku, Portugalsku, vel’vyslancom pri UNESCO či iniciátorom založenia Univerzity pre audiovizuálne umenia EFTA Paríž - Skopje - New York, kde v súčasnosti pôsobí ako rektor. Cudzinu však spoznával i predtým, a to diametrálne iným spôsobom - ako zametač na parížskom cintoríne Père Lachaise či ako člen skupiny iluzionistov, ktorá kočovala po Európe.

Slovenské knižné vydanie jeho drámy $R$ bolo trochu oneskorené, ale o to vítanejšie. Titul s nezvyčajným názvom vyšiel v pôvodine ešte v roku 1987, onedlho sa zrodil i jeho slovenský preklad, no publikovaný bol až v roku 2010, opät’ vo vydavatel'stve Juga. Jej prekladatel' a vydavatel' Ján Jankovič v predhovore knižného vydania nazvanom Jordan Plevneš - vzácny host' z Macedónska vysvetl'uje čitatel'om širšie súvislosti: „Fakt oneskoreného vydania je akosi v súlade aj s poznatkom, že slovensko-macedónske divadelné vztahy sú v porovnaní s bohatou prekladatel'skou a inscenačnou tradíciou drám ostatných národov bývalej Juhoslávie rozvinuté najmenej. Skutočnost', že hru publikujeme s istým časovým odstupom, svedčí aj o tom, že máme záujem udržovat’ a rozvíjat slovensko-macedónske vzt’ahy, no predovšetkým svedčí o kvalitách autora, jedného z najvýraznejších predstavitel’ov tretej generácie macedónskych dramatikov, ktorá vývin domáceho divadla začala výrazne ovplyv-

\footnotetext{
${ }^{11}$ STEFANOVSKI, G. Tetované duše (Vybrané dramatické práce), s. 181.

${ }^{12}$ Tamže.
} 
ňovat’ v polovici 70. rokov minulého storočia a súčasne prenikat’ do divadiel mimo svojej krajiny. " ${ }^{13}$

Dráma $R$ rozpráva popri inom o peripetiách komunikácie umelca pochádzajúceho z malého slovanského národa s ostatným svetom. Plevneš v nej pracuje s princípom divadla v divadle. Zároveň spletá motivickú siet’ z rôznych alúzií na macedónske dejiny aj aktuálnu svetovú politiku, pričom to robí pre neho typickým - utopickým či hyperbolickým - spôsobom. Na samotnom začiatku textu lapidárne uvádza, že sa „dej odohráva zajtra“ a dráma je venovaná „mojim priatel’om, bezhlasým aktérom Európy“. ${ }^{14}$ Umenie a politika sú v tejto dráme na rovine utopického (umeleckého) a ideologického v rovnováhe. Ústredný hrdina Maksim Brodski je známym a talentovaným hercom, čo indikuje, že autor napísal rolu pre skúseného interpreta, disponovaného narábat’ so širokou škálou výrazových prostriedkov, zvládnut prudké tempá, časté a nečakané zmeny rytmu predstavenia, odlíšit skutočnost’ od jej zdania, dnešok od minulosti a podobne. Usiloval sa o portrét hrdinu, ktorý síce žije v dravej a dynamickej dobe, no túži cítit’ sa ako súčast' harmonického celku v pevne ukotvenom priestore svojho národa. Plevneš využíva fejtonistickú konfrontáciu s minulostou, jeho hra je plná neočakávaných zvratov a nespútanej imaginácie. Všetko podstatné sa koncentruje v protagonistovi, prostredníctvom ktorého dramatik tlmočí svoje tézy a premieta život v jeho zložitosti. Maksim Brodski sa pripravuje na vystúpenie v zahraničí, pričom sa ocitá pod tlakom najrozličnejších okolností. Hra sa začína štrajkom, „súkromnou revolúciou“ predstavitel'a roly Robespierra z Büchnerovej hry Dantonova smrt'. Nasleduje dráma odohrávajúca sa v mysli umelca, ktorý sa zmieta medzi fikciou a realitou dneška, minulosti a budúcnosti. Plevnešov hrdina si chce splnił’ sen a zúčastnit’ sa sút’aže Herec Európy ${ }^{15}$ v Zürichu, no zažije obrovskú dezilúziu. Prostredníctvom postavy jeho otca Avrama sa tu navyše rieši i politický konflikt a konflikt dneška s minulostou. Maksim Brodski ako Avramov nasledovník stelesňuje revolúciu, uvedomuje si však, že ju treba najprv vybojovat’ vo vlastnom vnútri. Dráma priliehavo tematizuje národnú identitu, hojne pritom využívajúc prvky existencializmu. ${ }^{16}$

Popri menovaných publikovaných prekladoch macedónskych dramatikov existujú ešte d’alšie preklady, ktoré zostali z rozmanitých pragmatických alebo estetických príčin iba v rukopisoch. Ich prekladatel’om je literárny vedec Ján Jankovič. ${ }^{17}$ Spomedzi nich by sme mohli vyzdvihnút napr. drámu Candide v krajine zázrakov od Venka Andonovského (1964), opät’ so znakmi poetiky dislokácie. Ako postmodernistické dielo sa dá Candide v krajine zázrakov čítat na viacerých úrovniach. Nadväzuje pritom nielen na známe literárne texty či populárne filozofické smery. Miestami obsahuje i odkazy na l'udové rozprávky (napr. rozhovor medzi Babou-Král'om a Candidom je alúziou na známy dialóg z Červenej čiapočky) alebo históriu (napr. na spor s trojjazyč-

\footnotetext{
${ }^{13}$ JANKOVIČ, J. Jordan Plevneš - vzácny host’ z Macedónska. Predhovor, s. 5.

${ }^{14}$ PLEVNEŠ, Jordan. "R“ - Dramatický sen so striel'aním do abecedy v 15 obrazoch, s. 17.

${ }^{15}$ Pred niekol'kými rokmi sa práve Plevneš stal zakladatelom festivalu Herec Európy, ktorý sa spomína v dráme $R$. Udelenie prestížnej medzinárodnej ceny s rovnomenným názvom na spomenutom festivale sa koná každý rok na brehu Prespanského jazera v dnešnom Severnom Macedónsku. Tohtoročným laureátom sa stal, na podnet autora tejto štúdie a samotného Jordana Plevneša, slovenský herec Milan Kňažko.

${ }^{16}$ Podrobnejšie o tom pozri NAGYOVÁ, N. - TANESKI, Z. Téma národnej identity a prvky existencializmu v dráme Jordana Plevneša „, $\mathrm{R}^{\prime}$ (Dramatický sen so strielaním do abecedy v 15 obrazoch). In Király Péter 100 (Tanulmánykötet Király Péter Tiszteletére II.). Szerkesztette Császári Éva és Mária Imrichová. Budapest : ELTE BTK - Szláv Filológiai Tanszék, 2019, s. 261 - 269.

${ }^{17}$ Viac pozri Ján Jankovič v bibliografii a citátoch. Bratislava : Juga, 2003, s. 122 - 124.
} 
níkmi, ktorí v 9. storočí zastávali názor, že bohoslužby by sa mali slúžit len v troch jazykoch). Andonovského zámerom bolo načrtnút’ obraz Balkánu z nového pohladu. Na Macedónsko, kde sa hra odohráva, nazerá očami nevinného Candida, ktorého naivita sa stáva prostriedkom na vyjadrenie istej dávky spoločenskej kritiky. Cez perspektívu hlavnej postavy zistujeme, že pragmatický človek zo západnej Európy môže Balkán vnímat’ ako „krajinu zázrakov“. Ako miesto, kde neexistuje logika, kde sú nerest' a rozvrat (teda aspoň podl'a postavy Baby-Král'a) tými najkrajšími profesiami, kde sú všetci rovnakí a predsa rozdielni, a predovšetkým - kde sa, napriek vyššie zmienenému, všetko považuje za logické.

Po knižnom publikovaní prác macedónskych dramatikov sa rozšírila aj ich kritická recepcia, pričom pozitívne hodnotenia recenzentov prispeli k postupnému prenikaniu ich tvorby do slovenského kultúrneho povedomia. ${ }^{18}$ Napriek tomu ostáva inscenačná tradícia macedónskej drámy na Slovensku stále minimálna. Na sklonku sedemdesiatych rokov uviedla Nová scéna Bratislava hru Toma Arsovského Diogenov paradox (1979, preklad Ján Jankovič). Jediné uvedenie macedónskej drámy v období rokov 1989 - 2019, na ktoré je zameraná táto štúdia, sa odohralo v roku 1992, ked' umelecky vyspelý Divadelný súbor Jána Chalupku v Brezne inscenoval Stefanovského Tetované duše. Ochotníci vnímali ako osud malého národa, že kým iným republikám bývalej Juhoslávie sa slovenské divadelníctvo venovalo v adekvátnejšej miere, tak macedónsku drámu obchádzalo. Inscenáciu režíroval Ivan Hansman Jesenský z Báčskeho Petrovca, absolvent Akadémie umenia v Novom Sade, v tom čase už niekol'ko rokov žijúci na Slovensku. Podl’a jeho vyjadrenia je „naturel autora vel'mi blízky práve naturelu väčšiny Slovákov. Hra hovorí o živote malého národa vo vel'kom svete. Na skupine l’udí ilustruje Stefanovski márne snahy etablovat' sa a celé dianie vyjadruje v myšlienke: Tulene a malé národy sú pred vyhnutím, no tulene majú ešte šancu prežit.. " ${ }^{19}$

\section{MACEDONIAN DRAMA IN SLOVAKIA AFTER 1989}

\section{Zvonko TANESKI}

The aim of the paper is to examine the reception of Macedonian drama in Slovakia after 1989 and to provide an overview of the published book translations of

${ }^{18}$ Uvádzame všetky texty v chronologickom poradí podla ich vzniku. KRET, A. Balkánske vývery. In Slovenské divadlo, 2009, roč. 57, č. 2 - 3, s. 243 - 245; KRET, A. Edičná poznámka - Goran Stefanovski. In STEFANOVSKI, G. Tetované duše (Vybrané dramatické práce), s. 263 - 264; BODACZ, B. „R“ - Jordan Plevneš (Dramatický sen so striel’aním do abecedy v 15 obrazoch). In Slovenské pohl'ady, 2010, roč. 4 (+123), č. 9, s. 125 - 126; KRET, A. Jordan Plevneš - „R" (Dramatický sen so striel'aním do abecedy v 15 obrazoch). In PLEVNEŠ, J. "R" - Dramatický sen so striel'aním do abecedy v 15 obrazoch, s. 58; TANESKI, Z. Goran Stefanovski - Tetované duše. In Knižná revue, 2010, roč. 20, č. 5, s. 3; TANESKI, Z. Goran Stefanovski - Tetované duše Vybrané dramatické práce (Let na mieste, Tetované duše, Živé mäso, Hocikto, Čierna diera, Hi-Fi). In Revue svetovej literatúry, 2010, roč. 46, č. 2, s. 150 - 151; TANESKI, Z. O intímnej revolúcii macedónskeho Maksima Brodského (Jordan Plevneš). In Tvorba, 2010, roč. 20 (29), č. 2, s. 48 - 49; MIKUŠIAK, I. Vážna, iskrivá a znepokojujúca hra Jordana Plevneša v slovenčine. In Slovanský jih, 2011, roč. 11, č. 2, s. 30 - 31; NAGYOVÁ, N. - TANESKI, Z. Téma národnej identity a prvky existencializmu v dráme Jordana Plevneša „R“ (Dramatický sen so striel'aním do abecedy v 15 obrazoch). In Király Péter 100 (Tanulmánykötet Király Péter Tiszteletére II.), s. $261-269$.

${ }^{19}$ (dr). Celoštátna premiéra / Tetované duše - Goran Stefanovski. In Koridor, 5. 12. 1992. 
these dramas in the period under review. Within the topic in question, the author focuses mainly on the poetics of dislocation and on the issue of literary migration and its modification. His ambition is to present a document that will provide an overview of the nature, peculiarities and a specifically determined form of the presence of Macedonian drama in the Slovak cultural environment, while contemplating the phenomenon from an interdisciplinary point of view and simultaneously, from several different angles.

Štúdia je príspevkom k projektu VEGA 1/0321/19 Poetika dislokácie. Obraz imigranta v južnoslovanských literatúrach po roku 1989.

\section{LITERATÚRA}

(dr) Celoštátna premiéra / Tetované duše - Goran Stefanovski. In Koridor, 5. 12. 1992.

JANKOVIČ, Ján. Goran Stefanovski a macedónska dráma. Predhovor. In STEFANOVSKI, Goran. Tetované duše (Vybrané dramatické práce). Bratislava : Juga, 2009, s. 7 - 23. ISBN 978-8089030-42-2.

JANKOVIČ, Ján. Súvislosti alebo konspekt dejín macedónskej drámy. In STEFANOVSKI, Goran. Tetované duše (Vybrané dramatické práce). Bratislava : Juga, 2009, s. 39 - 59. ISBN 978-8089030-42-2.

JANKOVIČ, Ján. Jordan Plevneš - vzácny hosṫ z Macedónska. Predhovor. In PLEVNEŠ, Jordan. ${ }_{\text {"R }} R^{\prime \prime}$ - Dramatický sen so striel'aním do abecedy v 15 obrazoch. Bratislava : Juga, 2010, s. 5 - 15. ISBN 978-80-89030-48-4.

NAGYOVÁ, Nora - TANESKI, Zvonko. Téma národnej identity a prvky existencializmu v dráme Jordana Plevneša "R“ (Dramatický sen so striel'aním do abecedy v 15 obrazoch). In Király Péter 100 (Tanulmánykötet Király Péter Tiszteletére II.). Szerkesztette Császári Éva és Mária Imrichová. Budapest: ELTE BTK - Szláv Filológiai Tanszék, 2019, s. 261 - 269. ISBN 978-963-489-066-9.

PLEVNEŠ, Jordan. "R“ - Dramatický sen so striel'aním do abecedy v 15 obrazoch. Z macedónčiny preložil Ján Jankovič. Bratislava : Juga, 2010. 56 s. ISBN 978-80-89030-48-4.

STEFANOVSKI, Goran. Tetované duše (Vybrané dramatické práce). Z macedónčiny preložil Ján Jankovič. Bratislava: Juga, 2009. 264 s. ISBN 978-80-89030-42-2.

TANESKI, Zvonko. Goran Stefanovski - Tetované duše - Vybrané dramatické práce (Let na mieste, Tetované duše, Živé mäso, Hocikto, Čierna diera, Hi-Fi). In Revue svetovej literatúry, 2010, roč. 46, č. 2, s. 150 - 151. ISSN 0231-6269.

TANESKI, Zvonko. Dramatická tvorba v slovensko-macedónskych kultúrnych vztahoch od druhej polovice 20. storočia po súčasnosṫ. In TANESKI, Zvonko. Slovensko-macedónske literárne a kultúrne vzt’ahy. Bratislava : Juga / Ústav svetovej literatúry SAV, 2009, s. 131 -142. ISBN 978-80-89030-43-9.

TANESKI, Zvonko. O intímnej revolúcii macedónskeho Maksima Brodského (Jordan Plevneš). In Tvorba, 2010, roč. 20 (29), č. 2, s. 48 - 49. ISSN 1336-2526.

Zvonko Taneski

Katedra slovanských filológií

Filozofická fakulta Univerzity Komenského

Gondova 2

81499 Bratislava

zvonko.taneski@uniba.sk 